\title{
THE ROLE OF THYMOQUINONE IN AMELIORATING THE HEPATOXIC EFFECT OF DIAZINON IN MALE RATS
}

\author{
Emad W. Ghazy ${ }^{1}$, AbdAllah A. Mokh¹, Doaa H. Abdelhady ${ }^{1}$, Wael M. Goda², \\ Eman M. Hashem ${ }^{*}$
}

${ }^{1}$ Department of Clinical Pathology, Faculty of Veterinary Medicine, Kafrelsheikh University, Egypt, ${ }^{2}$ Department of clinical Pathology, Faculty of Veterinary Medicine, Damanhur University, Egypt

*Corresponding author, E-mail: eman.amr123.eh@gmail.com

\begin{abstract}
Diazinon (DZN) is one of most dangerous hepatotoxic organophosphorous insecticides used in veterinary practices which induces oxidative stress. The present study aimed to evaluate the ameliorative role of thymoquinone (TQ) in diazinon toxicity. Forty nine male albino rats and were divided into seven groups ( $n=7$ for each). The first group (c-ve group) orally received saline daily all over the experiment (8 weeks). The second group (c+ve1) orally received DZN (15 mg/kg body weight, b-w) for the first four weeks and saline for the next four weeks. The third group (c+ve2) orally received saline for the first four weeks and DZN (15 mg / $\mathrm{kg} \mathrm{b}-\mathrm{w})$ for the following four weeks. The fourth group (DZN-TQ $10 \mathrm{mg}$ group) received DZN (15 mg/kg b-w) daily for the first four weeks then TQ (10 mg/kg b-w) for the next four weeks. The fifth group (TQ $10 \mathrm{mg}-\mathrm{DZN}$ ) orally treated with TQ $(10 \mathrm{mg} / \mathrm{kg} \mathrm{b}-\mathrm{w})$ and DZN $(15 \mathrm{mg} / \mathrm{kg} \mathrm{b}-\mathrm{w})$ for the next for weeks. The sixth group (DZN-TQ $5 \mathrm{mg}$ group) received DZN (15 mg/kg b-w) for first four weeks and TQ (5 mg/kg b-w) for the following four weeks $5 \mathrm{mg}$. The seventh group treated by TQ $(5 \mathrm{mg} / \mathrm{kg} \mathrm{b}-\mathrm{w})$ daily for the first four weeks and DZN (15 mg/kg b-w) for the following four weeks (TQ 5 mg-DZN group). DZN intoxicated groups showed macrocytic hypochromic anemia and serum biochemical alteration related to liver injury, including elevation of alanine aminotransferase (ALT), aspartate aminotransferase (AST) and a significant decrease in total protein and albumin. Furthermore, these groups also exhibited a significant increase in liver tissue malondialdehyde (MDA), significant decrease in total antioxidant capacity (TAC) and catalase (CAT) activities and over-expression of the two apoptotic hepatic genes Bax and caspase 3. Administration of DZN also resulted in hepatic vacuolation, necrosis and congestion of hepatic sinusoids. Thymoquinone ameliorated the most deleterious effect of diazinon on hematological, biochemical, antioxidant, molecular and histopathological parameters in a dose dependent manner and a prophylactic strategy is better than therapeutic one.
\end{abstract}

Key words: diazinon; thymoquinone; oxidative stress; hepatotoxicity

Introduction

Received: January 2019

Accepted for publication: February 2019
Organophosphorous are still used as pesticides in agriculture, industry and in animal care as insecticides to control external parasites on 
animals all over the world. However, they are the most toxic pesticides to all animal species and human (1). The improper use of these pesticides is dangerous on human being and environment $(2,3)$. Organophosphorus insecticide residues are detectable in grains, crops, soil and some food products. Diazinon (DZN) considered as one of the most important organophosphorous compounds used in agriculture practices to control external parasites and flying insects of food crops and ornamental plants (4). It is also used to control the external parasites in veterinary practices. It was found that the main mechanism of action of DZN is inhibition of acetyl choline esterase enzyme (5). Furthermore DZN increased the level of malondialdehyde and lipid peroxidation biomarker in male rat (6).

Nowadays, the interest for using natural products for pharmacological purposes was increased. As this natural products gaining acceptance from the public, due to their useful effect on treatment of many disease without side effects which caused by many chemical products (7-9). Nigella sativa commonly known as black seed and black cumin. The essential oil and fixed oil of Nigella sativa showed powerful action in treatment of respiratory and gastrointestinal diseases (10). Furthermore, N. sativa has anti-oxidant, anti-inflammatory and hepatoprotective activities (11). Thymoquinone (TQ) is the most potent active constituent in the volatile oil of seeds of $N$. sativa. The possible mechanisms of TQ action including suppression of protein kinase $\mathrm{B}$ activation (Akt/PKB) by dephosphorylation (12), induction of apoptosis in cancerous cells by increasing apoptotic genes expression and decreasing anti-apoptotic gene expression $(13,14)$, induction of cytokines production (15) and activation of anti-oxidant enzymes (16). As result of these different beneficial effects of thymoquinone, TQ has various therapeutic effects such as anti-inflammatory effect (17), immune modulatory effect (18), free radical scavenger, antioxidant effect (19), anti-carcinogenic effect (20), apoptotic effect (21) and hepatoprotective effect by inhibiting lipid peroxidation (22). For this reasons, the present study aimed to assess the role of thymoquinone in alleviating the harmful effect of diazinon toxicity in male albino rats.

\section{Materials and methods}

\section{Chemicals}

Ectodat 60 EC, commercial formulation containing $60 \%$ of active ingredient (diazinon), was purchased from Kemet Company which imported the product from Jorden Company ATI. Thymoquinone was obtained from SigmaAldrich Company (product of china origin), CAS 490-9-5C10H12O2 MW 164.201 g/mol.

\section{Animals and treatments}

Forty nine male albino rats, purchased from Animal House Colony of Alexandria Center institute, weighting average $70 \pm 5 \mathrm{~g} /$ rat. The rats were kept in well ventilated animal house with a controlled dark -light cycle (12 h light $-12 \mathrm{~h}$ dark) and constant temperature $\left(26 \pm 2{ }^{\circ} \mathrm{C}\right)$ food and water were provided ad libitum.

Rats were allowed to accommodate two weeks before the start of the experiment. They were randomly divided into seven groups $(n=7$ for each group). The first group (c-ve group) orally received saline daily all over the experiment ( 8 weeks). The second group (c+ve1) orally received DZN (15 mg/kg body weight, b-w) (23) daily for the first four weeks and saline for the next four weeks. The third group (c+ve2) orally received saline for the first four weeks and DZN (15 mg/kg b-w) for the following four weeks. The fourth group (DZN-TQ 10 $\mathrm{mg}$ ) received DZN ( $15 \mathrm{mg} / \mathrm{kg} \mathrm{b}-\mathrm{w})$ for first four weeks then TQ (10 mg/kg b-w) (24) for the next four weeks. The fifth group (TQ $10 \mathrm{mg}$ DZN) orally treated by TQ $(10 \mathrm{mg} / \mathrm{kg} \mathrm{b}-\mathrm{w})$ daily and DZN (15 mg/kg b-w) for the next four weeks. The sixth group (DZN-TQ $5 \mathrm{mg}$ ) received DZN (15 mg/kg b-w) daily and TQ (5 $\mathrm{mg} / \mathrm{kg} \mathrm{b}-\mathrm{w}$ ) (20) for the following four weeks. The seventh group (TQ $5 \mathrm{mg}$-DZN) treated by TQ ( $5 \mathrm{mg} / \mathrm{kg} \mathrm{b}-\mathrm{w})$ for first four weeks then treated daily by DZN (15 mg/kg b-w) for the next four weeks.

Twenty four hours, after the end of the experiment, the blood samples were taken from retro-orbital venous plexus under effect of Di Ethyl Ether anesthesia and taken in aliquots 
with and without anti-coagulant for hematological and biochemical analysis, respectively. Blood samples without anticoagulant were left at room temperature to clot, then were centrifuged at $3000 \mathrm{rpm}$ for $15 \mathrm{~min}$ and the obtained were collected for biochemical analysis. Then rats were sacrificed by decapitation. The liver of each animal was rapidly removed, trimmed from excess tissues and washed by saline and distilled water. The liver samples divided into three parts; the first part used to preparation of tissue homogenate for determination antioxidant activities. The second part was cut into slices of about $0.1 \mathrm{~g}$ and directly put in liquid nitrogen then stored at $-80^{\circ} \mathrm{C}$ for molecular analysis. The last part was kept in $10 \%$ formalin to be used for histopathological examination. Animal rearing, handling and all experimental designs were approved by the Research Ethical Committee of faculty of veterinary medicine, Kafrelsheikh University, Egypt.

\section{Hematological examinations}

Aliquot containing EDTA $(1 \mathrm{mg} / \mathrm{ml})$ were used for determination of complete blood count (RBC, WBC, MCH, MCHC, PCV, platelets count, and differential leukocytic count) by using Sysmex-Xp 300 automatic hematological analyzer (25).

\section{Biochemical analysis}

Serum levels of liver damage marker (ALT and AST) were determined as previously described (26). Determination of total protein and albumin were determined according to (27) and (28) methods respectively using Genway spectrophotometer instrument. Determination of glucose was done by (29) method.

\section{Determination of oxidative stress/antioxi- dants}

The dissected tissues were washed by sodium phosphate buffered saline $(50 \mathrm{mmol} / \mathrm{l})$ with EDTA $(0.1 \mathrm{mmol} / \mathrm{l})$ in ice to remove any RBCs and clots. The tissues were homogenized in $5 \mathrm{ml}$ cold buffer /g of tissue then were centrifuged at $2000 \mathrm{rpm}$ for 20 minutes. The resulting supernatant was collected and preserved in $80^{\circ} \mathrm{C}$ for estimation of MDA (30), catalase
(CAT) (31) and total antioxidant capacity TAC (32).

\section{Histopathological examination}

Tissue preparation and histopathological examination were performed as previously described (33).

\section{Molecular investigation}

RNA extraction from hepatic tissue was applied using QIAamp RNeasy Mini kit (Qiagen, Germany, $\mathrm{GmbH}$ ) $\mathrm{GmbH}$ ) following manufacture protocol. A $25 \mu \mathrm{l}$ mixture containing 12.5 $\mu 1$ of the 2x Quantitect SYBR Green PCR Master Mix (Qiagen, Germany, GmbH), $0.25 \mu 1$ of Revert Aid Reverse Transcriptase (200 U/ $\mu \mathrm{L})$ (Thermo Fisher), $0.5 \mu \mathrm{l}$ of each primer of 20 pmol concentration (Table 1), $8.25 \mu$ l of water, and $3 \mu \mathrm{l}$ of RNA template was put in a Stratagene MX3005P real time PCR machine. Amplification curves and $\mathrm{Ct}$ values were determined by the Stratagene MX3005P software. To estimate the variation in gene expression, the $\mathrm{Ct}$ of each sample was compared with that of the positive control group according to the $2^{-\Delta \Delta c t}$ method (34).

\section{Statistical analysis}

For data analysis, Graph pad prism statistical package version 5.0 for windows was used. Differences in values were analyzed by one-way analysis of variance (ANOVA), followed by Tukey's multiple range test. All data expressed as mean \pm SEM, and the level of significance were cited at $\mathrm{p} \leq 0.05$.

\section{Results}

\section{Hematological findings}

Data explored in table (2) showed a significant ()$p \leq 0.05$ decrease in hematological parameters (RBCs, HGB and MCHC) and an insignificant decrease in (HCT, MCH and PLT) in DZN treated group (c+ve1). DZN c+ve2 group showed marked but not a significant decrease in hematological parameters (RBCs, HGB and PLT) and a significant decrease in HCT, MCH and MCHC. Significant $(p \leq 0.05)$ increase in MCV and WBCs was noticed in 
DZN treated groups as compared with the nontreated group (c-ve).

DZN-TQ $10 \mathrm{mg}$ group showed insignificant decrease in WBCs and a significant $(\mathrm{p} \leq 0.05)$ increase in hematological parameters (RBCs, $\mathrm{HCT}, \mathrm{MCH}$ and MCHC), similarly a marked increase in PLT but still in significant was also observed in DZN-TQ $10 \mathrm{mg}$ group as compared with the DZN treated group (c+ve1). TQ prophylactic group (TQ $10 \mathrm{mg}-\mathrm{DZN}$ ) showed marked increase in hematological parameters (RBCs, HCT, HGB, MCHC and PLT). Meanwhile, insignificant decrease in WBCs count was observed in this group as compared to the c+ve2 group. TQ therapeutic group (DZN-TQ $5 \mathrm{mg}$ ) showed a significant increase in RBCs and $\mathrm{MCHC}$ and a marked increase but still insignificant in $\mathrm{HCT}, \mathrm{HGB}, \mathrm{MCH}$ and PLT as compared with the c+ve1 group. TQ prophylactic group (TQ 5 mg-DZN) showed a marked increase in hematological parameters (HCT, HGB, MCH, MCHC and PLT) and a marked increase but still insignificant in RBCs as compared with the c+ve2 group.

\section{Serum biochemical parameters}

The harmful effect of diazinon toxicity and the useful effect of TQ on some biochemical parameters illustrated in table (2). Significant increase in serum level of (ALT and AST) in DZN treated groups (c+ve1 and c+ve2) as compared with non-treated group (c-ve). In contrast to this result, there was a significant decrease in total protein and albumin in DZN treated groups in comparison with c-ve group. Significant increase of glucose level in DZN treated groups as compared with c-ve group.

DZN-TQ $10 \mathrm{mg}$ showed a significant decrease in serum level of ALT, AST, glucose and a significant increase in TP and albumin as compared with c+ve1 group. In TQ prophylactic group (TQ $10 \mathrm{mg}$-DZN) showed marked decrease in serum ALT, AST, glucose and a significant increase in TP and albumin as compared with c+ve2group. TQ therapeutic group (DZN-TQ $5 \mathrm{mg}$ ) showed a significant decrease in ALT, AST and glucose. Meanwhile, significant increase in TP and albumin as compared with DZN treated group (c+ve1). TQ prophylactic group (TQ $5 \mathrm{mg}$-DZN), showed a significant decrease in serum biochemical parameters (ALT, AST and glucose) as compared with DZN treated group (c+ve2).

\section{Antioxidants biomarkers on liver tissues}

The antioxidant effect of TQ on DZN toxicity was shown in (Fig.2). DZN toxic groups (c+ve1 and c+ve2) illustrated significant decrease in TAC, Catalase activities and significant increase in MDA as compared with c-ve group. TQ therapeutic group (DZN-TQ $10 \mathrm{mg}$ ) showed a significant increase in TAC, Catalase activities and significant decrease in MDA as compared by c+ve1. TQ prophylactic group (TQ 10 mg-DZN) showed a significant increase in TAC, Catalase activities and a significant decrease in tissue MDA as compared with (c+ve2). TQ therapeutic group (DZN-TQ $5 \mathrm{mg}$ ) showed marked decrease of MDA but still insignificant and a significant increase in TAC and Catalase activities as compared with c+ve1 group. TQ prophylactic group (TQ $5 \mathrm{mg}-\mathrm{DZN}$ ) showed significant decrease in MDA and a significant increase in TAC, Catalase activities and as compared with c+ve2. Significant increase in TAC and CAT activities in TQ10 mg groups (prophylactic and therapeutic groups) as compared with TQ $5 \mathrm{mg}$ groups. TQ prophylactic groups (TQ $10 \mathrm{mg}-\mathrm{DZN}$ and TQ $5 \mathrm{mg}-\mathrm{DZN}$ ) showed a significant decrease in MDA as compared by TQ therapeutic groups (DZN-TQ 10 $\mathrm{mg}$ and DZN-TQ $5 \mathrm{mg}$ ).

Role of thymoquinone in ameliorating the histopathological alteration induced by diazinon

Data explored in (Fig.2) showed the histopathological alteration caused by DZN. Normal hepatocytes arranged in cords was observed in non-treated group (Fig.2A). DZN intoxicated group (c+ve1) showed marked congestion of hepatic sinusoids associated with atrophy of hepatocytes (Fig.2B), focal hepatic necrosis (Fig. 2Cm D). DZN intoxicated group (c+ve2) showed marked periportal inflammatory cells infiltration (Fig.2E), diffuse hepatic vacuolation (Fig.2F) and focal hepatic necrosis 
(Fig.2J). TQ reversed histopathological changes in liver tissues caused by DZN. (DZNTQ $10 \mathrm{mg}$ ) showed mild degree of granular hepatic vacuolation (Fig. $2 \mathrm{H})$ as compared with (c+ve1) group. (TQ $10 \mathrm{mg}-\mathrm{DZN}$ ) group showed mild degree of centrolobular vacuolation (Fig.2K) as compared with c+ve2 group. TQ therapeutic group (DZN-TQ $5 \mathrm{mg}$ ) showed periorbital inflammatory cells infilteration (Fig.2M), mild to moderate degree of granular hepatic vacuolation (Fig.2N) as compared with $\mathrm{c}+\mathrm{ve}$. TQ prophylactic group (TQ $5 \mathrm{mg}-\mathrm{DZN}$ ) showed mild to moderate degree of granular vacuolation (Fig.2O) as compared with c+ve2.

Effects of thymoquinone on Bax and caspase 3 gene expression in liver of DZN intoxicated rats

The expression of caspase 3 and Bax genes were significantly increased in liver of DZN in- toxicated groups (c+ve1 and c+ve2) as compared to non-treated group (c-ve) as showed in Fig.3. TQ therapeutic group (DZN-TQ $10 \mathrm{mg}$ ) illustrated a significant decrease in the levels of caspase 3 and Bax gene expression compared with DZN intoxicated group (c+ve1). The mRNA levels of caspase 3 and Bax were significantly downregulated in TQ prophylactic group (TQ $10 \mathrm{mg}$-DZN) as compared with the c+ve2 group. The gene expression of caspase 3 and Bax were significantly attenuated in TQ therapeutic group (DZN-TQ $5 \mathrm{mg}$ ) as compared with c+ve1 one. TQ prophylactic group (TQ 5 mg-DZN) showed a significant decrease of caspase 3 and Bax genes expression as compared with the c+ve2 group. The caspase and Bax genes expression was significantly decrease in (TQ $10 \mathrm{mg}$ ) groups as compared by (TQ $5 \mathrm{mg}$ ) groups.

Table 1: Primers used in qPCR

\begin{tabular}{lll}
\hline Gene & Primer sequence $\left(5^{\prime} \ldots \ldots . .33^{\prime}\right)$ & references \\
\hline$\beta$-actin & F:TCCTCCTGAGCGCAAGTACTCT & (Banni et al., 2010) \\
& R:GCTCAGTAACAGTCCGCCTAGAA &
\end{tabular}

BAX

F:CACCAGCTCTGAACAGATCATGA

(Kinouchi, 2003)

R:TCAGCCCATCTTCTTCCAGATGGT

Caspase3 F:AGTTGGACCCACCTTGTGAG

(Shi et al., 2009)

R:AGTCTGCAGCTCCTCCACAT

Table 2: Hematological and biochemical parameters of control and treated groups

\begin{tabular}{|c|c|c|c|c|c|c|c|}
\hline Parameters & c-ve & $\mathrm{c}+\mathrm{ve} 1$ & $\mathrm{c}+\mathrm{ve} 2$ & $\begin{array}{l}\text { DZN- } \\
\text { TQ10mg }\end{array}$ & $\begin{array}{l}\text { TQ10mg- } \\
\text { DZN }\end{array}$ & $\begin{array}{l}\text { DZN- } \\
\text { TQ5mg }\end{array}$ & TQ5mg-DZN \\
\hline $\mathrm{RBCs}\left(\times 10^{6} / \mu \mathrm{L}\right)$ & $7.6 \pm 0.22^{\mathrm{a}}$ & $5.8 \pm 0.16^{\mathrm{b}}$ & $6.4 \pm 0.5^{\mathrm{ab}}$ & $6.85 \pm 0.3^{\mathrm{a}}$ & $7.09 \pm 0.1^{\mathrm{a}}$ & $7.17 \pm 0.14^{\mathrm{a}}$ & $6.7 \pm 0.1^{\mathrm{ab}}$ \\
\hline $\operatorname{HCT}(\%)$ & $44.2 \pm 1.66^{\mathrm{a}}$ & $40.5 \pm 0.9^{\mathrm{ab}}$ & $40.1 \pm 0.9^{b}$ & $43.34 \pm 0.39^{a}$ & $45.2 \pm 0.56^{\mathrm{a}}$ & $41.2 \pm 0.84^{\mathrm{ab}}$ & $43.2 \pm 0.56^{\mathrm{a}}$ \\
\hline $\operatorname{HGB}(\mathrm{g} / \mathrm{dl})$ & $15.9 \pm 0.4^{\mathrm{a}}$ & $11.8 \pm 0.4^{\mathrm{b}}$ & $12.8 \pm 0.4^{\mathrm{ab}}$ & $15.2 \pm 0.39^{\mathrm{a}}$ & $15.1 \pm 0.13^{\mathrm{a}}$ & $14.4 \pm 0.4^{\mathrm{ab}}$ & $15.8 \pm 0.12^{\mathrm{a}}$ \\
\hline MCV(FL) & $57.1 \pm 0.4^{\mathrm{bc}}$ & $71.3 \pm 1.3^{\mathrm{a}}$ & $66.5 \pm 1.6^{\mathrm{a}}$ & $58.1 \pm 0.44^{\mathrm{b}}$ & $59.3 \pm 1.07^{\mathrm{ab}}$ & $61 \pm 0.12^{\mathrm{ab}}$ & $59.3 \pm 1.07^{\mathrm{ab}}$ \\
\hline MCH(pg.) & $21 \pm 0.48^{\mathrm{ab}}$ & $20.4 \pm 0.3^{\mathrm{ab}}$ & $19.6 \pm 0.3^{b}$ & $22.1 \pm 0.1^{\mathrm{a}}$ & $21 \pm 0.12^{\mathrm{ab}}$ & $20.08 \pm 0.14^{\mathrm{ab}}$ & $23.5 \pm 0.12^{\mathrm{a}}$ \\
\hline $\mathrm{MCHC}(\mathrm{g} / \mathrm{dl})$ & $35.9 \pm 0.3^{\mathrm{a}}$ & $29.7 \pm 1.3^{\mathrm{b}}$ & $31.9 \pm 0.8^{\mathrm{b}}$ & $35 \pm 0.06^{\mathrm{a}}$ & $34.6 \pm 0.06^{\mathrm{a}}$ & $34.9 \pm 0.12^{\mathrm{a}}$ & $34.6 \pm 0.06^{\mathrm{a}}$ \\
\hline $\operatorname{PLT}\left(\times 10^{3} / \mu \mathrm{l}\right)$ & $1080 \pm 174^{\mathrm{a}}$ & $741 \pm 63.6^{\mathrm{ab}}$ & $710 \pm 28.4^{\mathrm{ab}}$ & $1004.3 \pm 127^{\mathrm{ab}}$ & $1133.6 \pm 36^{\mathrm{a}}$ & $993 \pm 54^{\mathrm{ab}}$ & $1077 \pm 116^{\mathrm{a}}$ \\
\hline $\operatorname{WBCs}\left(\times 10^{3} / \mu 1\right)$ & $10.5 \pm 1.7^{\mathrm{b}}$ & $24.7 \pm 4.5^{\mathrm{a}}$ & $22.3 \pm 4.7^{\mathrm{a}}$ & $12.1 \pm 0.4^{\mathrm{ab}}$ & $12.1 \pm 1.3^{\mathrm{ab}}$ & $11.9 \pm 0.6^{\mathrm{ab}}$ & $14.5 \pm 0.14^{\mathrm{ab}}$ \\
\hline $\operatorname{ALT}(\mathrm{U} / \mathrm{l})$ & $14.6 \pm 6.69^{\mathrm{cd}}$ & $92.9 \pm 0.97^{\mathrm{a}}$ & $73 \pm 4.6^{\mathrm{a}}$ & $41 \pm 1.4^{\mathrm{b}}$ & $43.03 \pm 5.6^{\mathrm{bc}}$ & $43 \pm 1.6^{\mathrm{b}}$ & $39.5 \pm 2.2^{\mathrm{b}}$ \\
\hline AST(U/l) & $36 \pm 8.1^{\mathrm{bc}}$ & $94 \pm 11.24^{\mathrm{a}}$ & $101 \pm 23^{\mathrm{a}}$ & $52.5 \pm 2.6^{\mathrm{b}}$ & $47.16 \pm 1.9^{\mathrm{bc}}$ & $65.7 \pm 0.8^{\mathrm{b}}$ & $57.8 \pm 8^{b}$ \\
\hline $\mathrm{TP}(\mathrm{g} / \mathrm{dl})$ & $8.4 \pm 0.24^{\mathrm{a}}$ & $5.7 \pm 0.088^{c}$ & $6.12 \pm 0.10^{c}$ & $7.32 \pm 0.26^{\mathrm{b}}$ & $7.3 \pm 0.080^{\mathrm{b}}$ & $7.38 \pm 0.27^{\mathrm{b}}$ & $5.9 \pm 0.134^{\mathrm{c}}$ \\
\hline Albumin $(\mathrm{g} / \mathrm{dl})$ & $4 \pm 0.1^{\mathrm{a}}$ & $3.9 \pm 0.13^{\mathrm{b}}$ & $3.3 \pm 0.05^{\mathrm{b}}$ & $4.1 \pm 0.05^{\mathrm{a}}$ & $4 \pm 0.01^{\mathrm{a}}$ & $4.15 \pm 0.05^{\mathrm{a}}$ & $3.7 \pm 0.05^{\mathrm{ab}}$ \\
\hline Glucose (mg/dl) & $102 \pm 4.8^{\mathrm{c}}$ & $145 \pm 7.6^{\mathrm{a}}$ & $163 \pm 1.5^{\mathrm{a}}$ & $121 \pm 1.3^{\mathrm{b}}$ & $116 \pm 1.67^{b}$ & $128 \pm 0.2^{\mathrm{b}}$ & $117.6 \pm 3.28^{\mathrm{b}}$ \\
\hline
\end{tabular}

Notes; the data are expressed as $\pm \mathrm{SE}(\mathrm{n}=7)$. Different upper case letters within a row indicate different mean value $(\mathrm{p} \leq 0.05)$. TQ, thymoquinone; DZN, diazinon; RBCs, red blood cells; HCT, hematocrit; HGB, hemoglobin; MCH, mean corpuscular hemoglobin; MCHC, mean corpuscular hemoglobin concentration; PLT, platelets; WBCs, white blood cells, ALT, alanine aminotransferase; AST, aspartate aminotransferase; TP, total protein. 

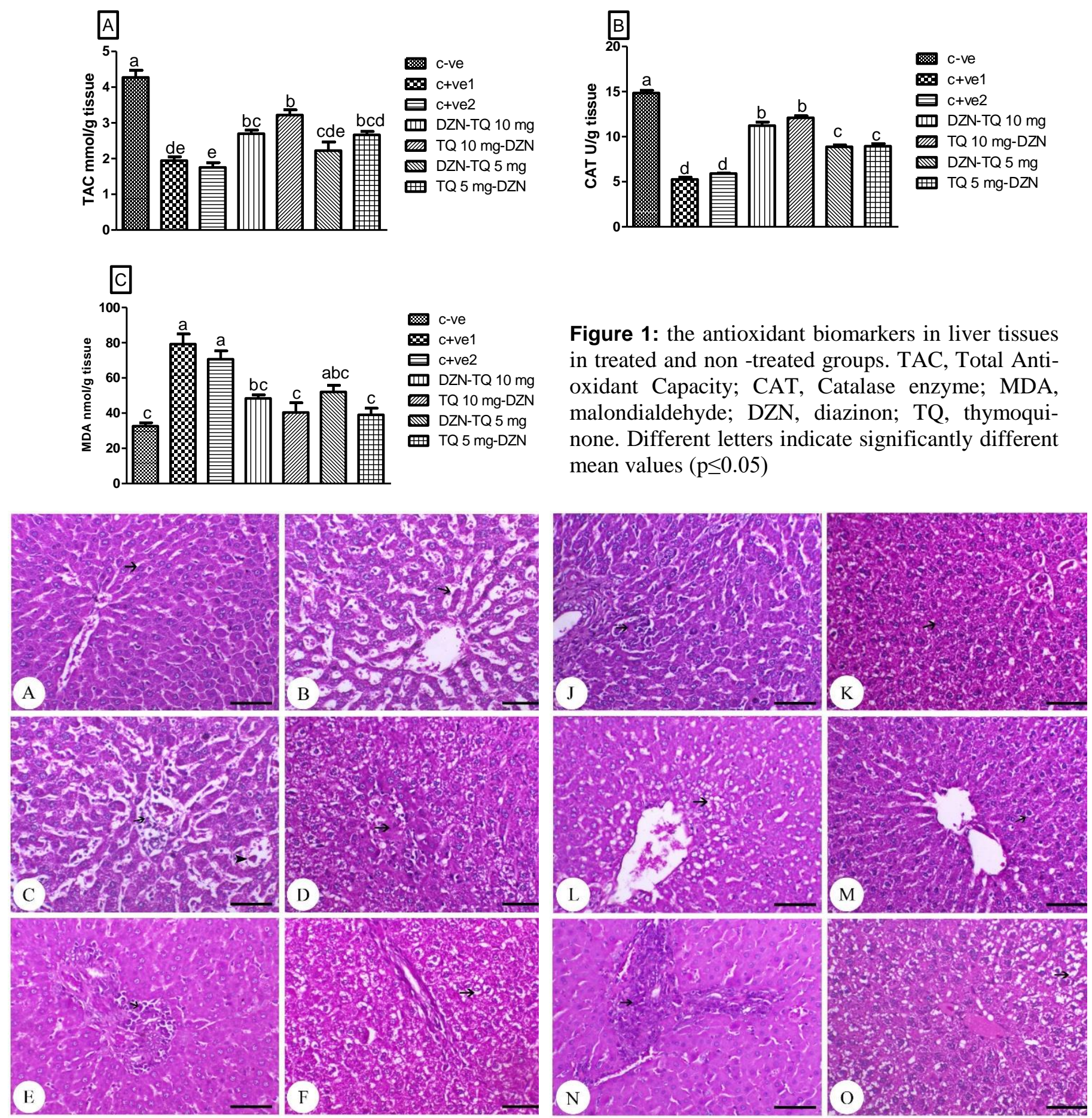

Figure 1: the antioxidant biomarkers in liver tissues in treated and non -treated groups. TAC, Total Antioxidant Capacity; CAT, Catalase enzyme; MDA, malondialdehyde; DZN, diazinon; TQ, thymoquinone. Different letters indicate significantly different mean values $(\mathrm{p} \leq 0.05)$

Figure 2: A; Liver of rat of non-treated group showing normal hepatocytes arranged in cords (arrow). B; Liver of animal from (c+ve1) showing marked congestion of the hepatic sinusoids (arrow). C; Liver of animal from (c+ve1) showing focal hepatic necrosis (arrowhead). D; Liver of animal from (c+ve1) showing focal hepatic necrosis (arrow). E; Liver of animal from (c+ve2) group showing marked periportal inflammatory cells infiltration with presence of few eosinophils (arrow). F; Liver of animal from (c+ve2) group showing diffuse vacuolation of hepatocytes (arrow). $\mathrm{J}$; Liver of normal animal (c+ve2) showing focal hepatic necrosis (arrow). K; Liver of normal animal (DZN-TQ 10 $\mathrm{mg}$ ) group showing mild degree of granular hepatic vacuolation (arrow). L; Liver of normal animal (TQ $10 \mathrm{mg}-\mathrm{DZN}$ ) group showing mild degree of centrolobular vacuolation (arrow). M; Liver of normal animal (DZN-TQ $5 \mathrm{mg}$ ) group showing periportal inflammatory cells infiltration (arrow). N; Liver of normal animal (DZN-TQ $5 \mathrm{mg}$ ) group showing mild to moderate degree of granular vacuolation (arrow). O; Liver of normal animal (TQ 5 mg-DZN) group showing mild to moderate degree of granular hepatic vacuolation (arrow). H\&E, bar $=100 \mu \mathrm{m}$ 


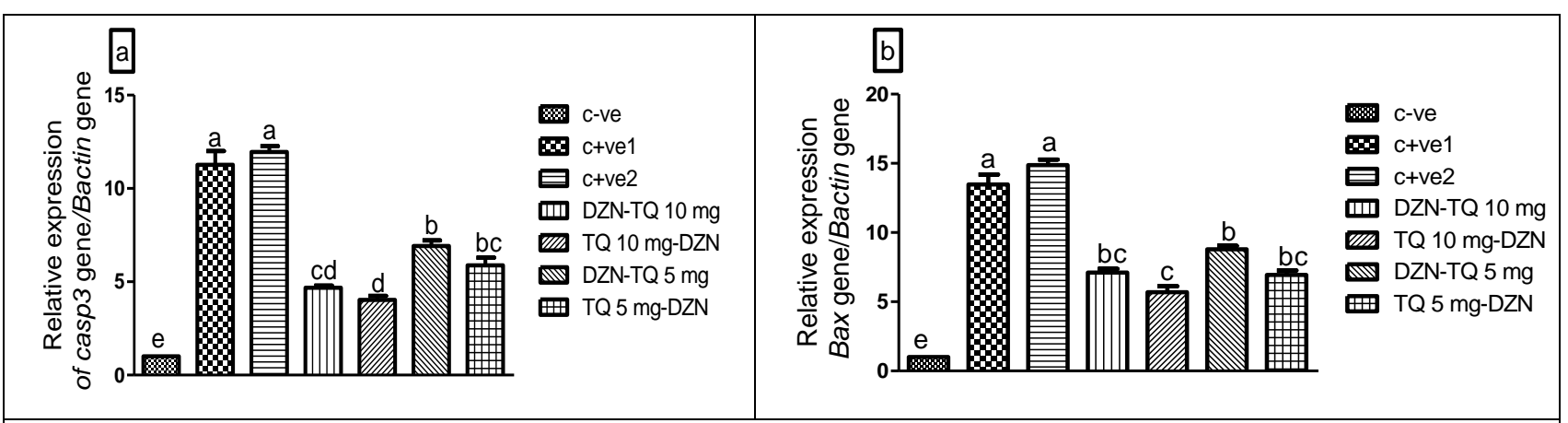

Figure 3: Caspase 3 and Bax gene expresion in treated and non-treated groups. Data are presented as mean (fold change) \pm SEM $(\mathrm{n}=5)$. Column carrying different superscript letters are sigbificantly different at $\mathrm{P} \leq$ 0.05

\section{Discussion}

The present study investigated the effect of two different doses of TQ as prophylactic and therapeutic on the toxic effects of DZN organophosphorous insecticide through investigation of hematological, biochemical, lipid peroxidation, antioxidant biomarker, molecular and histopathological alterations. The results of the present study revealed a significant reduction in hemogram (RBCs, $\mathrm{HGB}, \mathrm{MCH}, \mathrm{MCHC}$ and PLT) and increase in MCV and total leucocytic count (TLC) in DZN intoxicated group. These data agree with (35, 36) and indicate the presence of macrocytic hypochromic anemia. DZN can cause destruction of RBCs (37) as it increase production reactive oxgen species (ROS) which have adverse effect on membrane and macromolucules of erthrocytes as it induces osmotic fragility, decreases cellular deformability and damage cell membrane (38). The development of macrocytic hypochromic anemia may be due to either interference of DZN with HGB biosynthesies or decrease life span of erthrocytes (39). (40) reported that the decrease in RBCs count and HGB biosynthesies due to effect of DZN on bone marrow tissues. The increase in MCV and decrease in MCHC suggested that hemolytic or haemorragic anemia. The increase in WBCs count in DZN intoxicated group aggree with (36). As a result of tissue injury caused by DZN, increase level of tissue malondiadehyde consequently activation of immune system (41) and calling the inflamatory cells and this resulted in an increasing in total leucocytic count. The reduction of PLT may be due to the effect of free radicals on bone marrow which decreased PLT production or depressed thrombopoiesis (42).

The enhancement in hepatocellular injuries could be refered to the production of ROS which accelerate lipid peroxidation and increase production of toxic aldyhde. The exhaustion of antioxidant defense mechanism may led to damage of hepatocytes and release of interacellular enzymes like ALT and AST enzymes. These results run parellel with (36). These suggestion is supported by liver histopathological finding which include diffuse hepatic vacuolation, mononucler cell infilteration and hepatic necrosis. As a result of toxic damage of DZN on liver tissues, the liver can not perform the function of synthesis of different types of protiens, this finding was confirmed by decrease serum level of total protien and albumin (43).

(44) approved that DZN led to increase in serum glucose level as illustrated in this study. The increment in serum glucose could be attributed to oxidative stress caused by DZN which stimulate gluconeogenesis and glycogenolysis (45).

Diazinon enhances MDA production which is considered as one of most critical indicator of oxidative stress and lipid peroxidation (46). (6) reported that diazinon enhances oxidative stress leads to production of free radicals and alteration of free radical scavengers enzymes 
(antioxidants enzymes) in different tissues. In the present study there was an increase in the level of MDA, a decrease in TAC and catalase activities in DZN treated group. These data agree with $(47,48)$.

DZN causes toxic injury to hepatocytes and increase number of apopototic cells within hepatic tissues (6). The current study showed DZN increased expression of Bax and caspase 3 genes. The harmful effect of DZN on mitochondria through increase its membrane permeability and ROS production. Bax is a proapoptotic gene which has an important role in release of cytochrome $\mathrm{c}$ which subsequently activates procaspase 9 and activation of intrinsic apopototic pathway. Procaspase 9 (the intiator) activates streams of caspases including caspase 3 (49). caspase 3 responsible for cleavation of specific target protien which lead to apoptosis (increase number of apopoyotic cells).

The current study demonstrated that TQ by different doses $(5 \mathrm{mg}$ and $10 \mathrm{mg}$ ) and as either prophylactic or therapeutic ameloriated the toxic effect of DZN. This may be due to TQ antioxidants activities and free radical scavanging properities that protect against oxidative damage (50). TQ alleviated the toxic effect of DZN on hemogram. These results run parallel with those obtained by (51). TQ counteract the increase in TLC caused by DZN may be due to either supression of cell mediated immune response (52) or its anti inflamatory properties (11). Administration of TQ alleviated the toxic effect of diazinon on liver tissues. TQ reduced serum ALT, AST and increased TP and albumin because of its hepatoprotective properities $(22,53)$ as thymoquinone stimulate the antioxidant scavenging enzymes system (i.e catalase, glutathione, superoxide dismutase). This effect is supported by histopathological changes caused by TQ as mild to moderate degree of hepatic vacuolation. In this study TQ make reduction in glucose level and this reduction may be due to inhibition of hepatic gluconeogenesis (54). (55) reported that TQ reduced hepatic antioxidants enzymes activities (i.e TAC and catalase) and this agree with this study. The stimulatory effect of TQ on hepatic antioxidant enzymes activities with hepatic lipid peroxidation reduction could be attributed to its free radical scavenging abilities and its ability to compansate the depleted antioxidant enzymes (56). Our study showed that TQ significantly attenuated hepatic apopotosis. As TQ supresses the release of cytochrome $\mathrm{c}$ which is a key of intrinsic apoptotic pathway, subsequently TQ reduced apoptosis and this indicated by molecular investigation which illusterated significant decrease in Caspase 3 and Bax gene expression (57) and histopathological finding which confirmed by marked decrease in apoptotic cells. These results showed a significant decrease in Bax and caspase 3 gene expression in a prophylactic and therapeutic (TQ $10 \mathrm{mg}$ ) groups as compared with (TQ $5 \mathrm{mg}$ ) groups (58)

\section{Conclusion}

TQ has prophylactic and therapeutic abilities to countract the deterious effects of DZN due to free radical scavenging and antioxidant properities of TQ. The degree of development is dose dependant and aprophylactic supplementation is better than therapeutic one.

\section{Conflict of interest}

I would to thank my family and Co-Vet Office for finincial support.

\section{References}

1. Shah M D, Iqbal M. Diazinon-induced oxidative stress and renal dysfunction in rats, Food and chemical toxicology 2010; 48(12): 3345-53.

2. Grant W F, Cytogenetic studies of agricultural chemicals in plants, Genetic Toxicology, Springer1982, pp. 353-78.

3. Casas E, Bonilla E, Ducolomb Y, Betancourt M. Differential effects of herbicides atrazine and fenoxaprop-ethyl, and insecticides diazinon and malathion, on viability and maturation of porcine oocytes in vitro, Toxicology in vitro 2010; 24(1): 224-30.

4. Sarhan O, Al-Sahhaf Z. Histological and biochemical effects of diazinon on liver and kidney of rabbits, Life Science Journal 2011; 8(4): 1183-9.

5. Kamanyire R, Karalliedde L. Organophosphate toxicity and occupational exposure, Occupational medicine 2004; 54(2): 69-75. 
6. Ogutcu A, Uzunhisarcikli M, Kalender S, Durak D, Bayrakdar F, Kalender Y. The effects of organophosphate insecticide diazinon on malondialdehyde levels and myocardial cells in rat heart tissue and protective role of vitamin $\mathrm{E}$, Pesticide biochemistry and physiology 2006; 86(2): 93-8.

7. Panda V S, Naik S R. Evaluation of cardioprotective activity of Ginkgo biloba and Ocimum sanctum in rodents, Alternative Medicine Review 2009; 14(2): 161.

8. Abu Gazia M, El-Magd M A. Effect of pristine and functionalized multiwalled carbon nanotubes on rat renal cortex, Acta Histochemica, https://doi.org/10.1016/j.acthis.2018.12.005 2018.

9. Abu Gazia M, El-Magd M A. Ameliorative Effect of Cardamom Aqueous Extract on Doxorubicin-Induced Cardiotoxicity in Rats, Cells Tissues Organs, DOI: 10.1159/000496109. 2019.

10. Ali B, Blunden G. Pharmacological and toxicological properties of Nigella sativa, Phytotherapy Research: An International Journal Devoted to Pharmacological and Toxicological Evaluation of Natural Product Derivatives 2003; 17(4): 299-305.

11. Entok E, Ustuner M C, Ozbayer C, Tekin N, Akyuz F, Yangi B, Kurt H, Degirmenci I, Gunes H V. Anti-inflammatuar and anti-oxidative effects of Nigella sativa L.: 18 FDG-PET imaging of inflammation, Molecular biology reports 2014; 41(5): 2827-34.

12. Yi T, Cho S-G, Yi Z, Pang X, Rodriguez M, Wang Y, Sethi G, Aggarwal B B, Liu M. Thymoquinone inhibits tumor angiogenesis and tumor growth through suppressing AKT and extracellular signal-regulated kinase signaling pathways, Molecular cancer therapeutics 2008; 7(7): 1789-96.

13. El-Mahdy M A, Zhu Q, Wang Q E, Wani G, Wani A A. Thymoquinone induces apoptosis through activation of caspase- 8 and mitochondrial events in p53-null myeloblastic leukemia HL-60 cells, International journal of cancer 2005; 117(3): 409-17.

14. Torres M P, Ponnusamy M P, Chakraborty S, Smith L M, Das S, Arafat H A, Batra S K. Effects of thymoquinone in the expression of mucin 4 in pancreatic cancer cells: implications for the development of novel cancer therapies, Molecular cancer therapeutics 2010: 1535-7163. MCT-100075.

15. Öberg F, Haseeb A, Ahnfelt M, Pontén F, Westermark B, El-Obeid A. Herbal melanin activates TLR4/NF- $\mathrm{kB}$ signaling pathway, Phytomedicine 2009; 16(5): 477-484.

16. Ismail M, Al-Naqeep G, Chan K W. Nigella sativa thymoquinone-rich fraction greatly improves plasma antioxidant capacity and expression of antioxidant genes in hypercholesterolemic rats, Free Radical Biology and Medicine 2010; 48(5): 664-72.

17. Abdel-Fattah A-F M, Matsumoto K, Watanabe H. Antinociceptive effects of Nigella sativa oil and its major component, thymoquinone, in mice, European journal of pharmacology 2000; 400(1): 89-97.

18. Salem M L. Immunomodulatory and therapeutic properties of the Nigella sativa L. seed, International immunopharmacology 2005; 5(1314): 1749-70.

19. Ashraf S S, Rao M V, Kaneez F S, Qadri S, Al-Marzouqi A H, Chandranath I S, Adem A. Nigella sativa extract as a potent antioxidant for petrochemical-induced oxidative stress, Journal of chromatographic science 2011; 49(4): 321-6.

20. Talib W H, AbuKhader M M. Combinatorial effects of thymoquinone on the anticancer activity and hepatotoxicity of the prodrug CB 1954, Scientia pharmaceutica 2013; 81(2): 519.

21. Arafa E-S A, Zhu Q, Shah Z I, Wani G, Barakat B M, Racoma I, El-Mahdy M A, Wani A A. Thymoquinone up-regulates PTEN expression and induces apoptosis in doxorubicin-resistant human breast cancer cells, Mutation Research/Fundamental and Molecular Mechanisms of Mutagenesis 2011; 706(1): 28-35.

22. Aycan İ Ö, Tüfek A, Tokgöz O, Evliyaoğlu O, Firat U, Kavak G Ö, Turgut H, Yüksel M U. Thymoquinone treatment against acetaminopheninduced hepatotoxicity in rats, International Journal of Surgery 2014; 12(3): 213-8.

23. Razavi B, Hosseinzadeh H, Imenshahidi M, Malekian M, Ramezani M, Abnous K. Evaluation of protein ubiquitylation in heart tissue of rats exposed to diazinon (an organophosphate insecticide) and crocin (an active saffron ingredient): role of HIF-1 $\alpha$, Drug research 2015; 65(11): 561-6.

24. Helal G K. Thymoquinone supplementation ameliorates acute endotoxemia-induced liver dysfunction in rats, Pakistan journal of pharmaceutical sciences 2010; 23(2).

25. El-Magd M A, Khamis A, Nasr Eldeen S K, Ibrahim W M, Salama A F. Trehalose enhances the antitumor potential of methotrexate against mice bearing Ehrlich ascites carcinoma, Biomedicine \& Pharmacotherapy 2017; 92: 870-8. 
26. Elkeiy M, Khamis A, El-Gamal M, Abo Gazia M, Zalat Z, El-Magd M. Chitosan nanoparticles from Artemia salina inhibit progression of hepatocellular carcinoma in vitro and in vivo, Environ Sci Pollut Res Int. doi: 10.1007/s11356-018-3339-6 2018.

27. Solberg H, Burtis C, Ashwood E, Tietz Textbook of Clinical Chemistry, WB Saunders Philadelphia, PA, 1999.

28. Rodkey F L. Binding of bromocresol green by human serum albumin, Archives of Biochemistry and Biophysics 1964; 108(3): 510-3.

29. Trinder P. Determination of serum cholesterol by enzymatic colorimetric method, Ann Clin Biochem 1969; 6(24): 7.

30. Abdelhady D H, El-Magd M A, Elbialy Z I, Saleh A A. Bromuconazole-induced hepatotoxicity is accompanied by upregulation of PXR/CYP3A1 and downregulation of CAR/CYP2B1 gene expression, Toxicol Mech Methods 2017; 27(7): 544-50.

31. Sinha A K. Colorimetric assay of catalase, Analytical biochemistry 1972; 47(2): 389-394.

32. Koracevic D, Koracevic G, Djordjevic V, Andrejevic S, Cosic V. Method for the measurement of antioxidant activity in human fluids, Journal of clinical pathology 2001; 54(5): 356-61.

33. Fatima I, Iqbal R, Hussain M. Histopathological effects of Chromium (III) Sulfate on Liver and Kidney of Swiss Albino Mice (Mus musculus), Asia Pacific Journal of Multidisciplinary Research 2016; 4(3): 175-80.

34. Yuan J S, Reed A, Chen F, Stewart C N. Statistical analysis of real-time PCR data, BMC bioinformatics 2006; 7(1): 85 .

35. Abdel-Daim M M, Taha R, Ghazy E W, ElSayed Y S. Synergistic ameliorative effects of sesame oil and alpha-lipoic acid against subacute diazinon toxicity in rats: hematological, biochemical, and antioxidant studies, Canadian journal of physiology and pharmacology 2015; 94(1): 81-8.

36. Yassa V F, Girgis S M, Abumourad I M. Potential protective effects of vitamin $\mathrm{E}$ on diazinon-induced DNA damage and some haematological and biochemical alterations in rats, Journal of Mediterranean Ecology 2011; 11: 31-9.

37. Rajini P, Viswanatha S, Krishnakumari M. Effect of pirimiphos-methyl, an organophosphorus insecticide on hematological parameters in albino rats, Indian journal of experimental biology 1987; 25(3): 190-3.
38. Hogg N, Free radicals in disease, Seminars in reproductive endocrinology, Copyright $(\mathrm{C} 1998$ by Thieme Medical Publishers, Inc., 1998, pp. 241-8.

39. Patil J A, Patil A J, Govindwar S P. Biochemical effects of various pesticides on sprayers of grape gardens, Indian journal of clinical biochemistry 2003; 18(2): 16-22.

40. Kalender Y, Uzunhisarcikli M, Ogutcu A, Acikgoz F, Kalender S. Effects of diazinon on pseudocholinesterase activity and haematological indices in rats: the protective role of vitamin $\mathrm{E}$, Environmental toxicology and pharmacology 2006; 22(1): 46-51.

41. Yehia M A, El-Banna S G, Okab A B. Diazinon toxicity affects histophysiological and biochemical parameters in rabbits, Experimental and Toxicologic pathology 2007; 59(3-4): 215-225.

42. Elsharkawy E E, Yahia D, El-Nisr N A. Subchronic exposure to chlorpyrifos induces hematological, metabolic disorders and oxidative stress in rat: attenuation by glutathione, Environmental toxicology and pharmacology 2013; 35(2): 218-27.

43. Hariri A T, Moallem S A, Mahmoudi M, Memar B, Hosseinzadeh H. Sub-acute effects of diazinon on biochemical indices and specific biomarkers in rats: protective effects of crocin and safranal, Food and chemical toxicology 2010; 48(10): $2803-8$.

44. Ueyama J, Kamijima M, Asai K, Mochizuki A, Wang D, Kondo T, Suzuki T, Takagi K, Takagi $\mathrm{K}$, Kanazawa $\mathrm{H}$. Effect of the organophosphorus pesticide diazinon on glucose tolerance in type 2 diabetic rats, Toxicology letters 2008; 182(1-3): 42-7.

45. Alahyary P, Poor M I, Azarbaijani F F, Nejati V. The potential toxicity of diazinon on physiological factors in male rat, Pak J Biol Sci 2008; 11: 127-30.

46. Nair V, O’Neil C, Wang P. Malondialdehyde. Encyclopedia of reagents for organic synthesis, Retrieved Feb 2008; 26: 2009.

47. Lari P, Abnous $K$, Imenshahidi $M$, Rashedinia M, Razavi M, Hosseinzadeh $\mathrm{H}$. Evaluation of diazinon-induced hepatotoxicity and protective effects of crocin, Toxicology and industrial health 2015 ; 31(4): 367-76.

48. El-Shenawy N S, El-Salmy F, Al-Eisa R A, El-Ahmary B, Amelioratory effect of vitamin E on organophosphorus insecticide diazinon-induced oxidative stress in mice liver, Pesticide biochemistry and physiology, 2010, pp. 101-7.

49. Wang K. Molecular mechanisms of hepatic apoptosis, Cell death \& disease 2015; 5(1): e996. 
50. Nagi M N, Almakki H A, Sayed-Ahmed M M, Al-Bekairi A M. Thymoquinone supplementation reverses acetaminophen-induced oxidative stress, nitric oxide production and energy decline in mice liver, Food and Chemical Toxicology 2010; 48(8-9): 2361-5.

51. Danaei G H, Karami M. Protective effect of thymoquinone against diazinon-induced hematotoxicity, genotoxicity and immunotoxicity in rats, Environmental toxicology and pharmacology 2017; 55: 217-2.

52. Gholamnezhad Z, Keyhanmanesh R, Boskabady M H. Anti-inflammatory, antioxidant, and immunomodulatory aspects of Nigella sativa for its preventive and bronchodilatory effects on obstructive respiratory diseases: A review of basic and clinical evidence, Journal of Functional Foods 2015; 17: 910-27.

53. Daba M H, Abdel-Rahman M S. Hepatoprotective activity of thymoquinone in isolated rat hepatocytes, Toxicology Letters 1998; 95(1): 23-9.

54. Mohamed A, El-Sharkawy F, Ahmed S, Aziz W, Badary O. Glycemic control and therapeutic effect of Nigella sativa and Curcuma longa on rats with streptozotocin-induced diabetic hepatopathy, Journal of Pharmacology and Toxicology 2009; 4(2): 45-57.

55. Mansour M A, Nagi M N, El-Khatib A S, AlBekairi A M. Effects of thymoquinone on antioxidant enzyme activities, lipid peroxidation and DT-diaphorase in different tissues of mice: a possible mechanism of action, Cell biochemistry and function 2002; 20(2): 143-51.

56. Al-Attar A M, Elnaggar M H, Almalki E A. Protective effect of some plant oils on diazinon induced hepatorenal toxicity in male rats, Saudi journal of biological sciences 2017; 24(6): 1162-71.

57. El-Ghany R, Sharaf N, Kassem L, Mahran L, Heikal O. Thymoquinone triggers anti-apoptotic signaling targeting death ligand and apoptotic regulators in a model of hepatic ischemia reperfusion injury, Drug Discov Ther 2009; 3(6): 296-306.

58. Nili-Ahmadabadi A, Alibolandi P, Ranjbar A, Mousavi L, Nili-Ahmadabadi H, LarkiHarchegani A, Ahmadimoghaddam D, Omidifar N. Thymoquinone attenuates hepatotoxicity and oxidative damage caused by diazinon: an in vivo study, Research in pharmaceutical sciences 2018; 13(6): 500. 